\title{
VIRUS KORONA: PENEGUH NILAI-NILAI DALAM AJARAN ISLAM
}

\author{
Iu Rusliana \\ $\overline{\text { UIN Sunan Gunung Djati }}$ \\ iurusliana@uinsgd.ac.id
}

\begin{abstract}
Abstrak
Artikel ini berusaha menggali nilai-nilai dalam ajaran Islam yang perlu diperkuat agar dapat menjadi peneguh sikap keberagamaan untuk melewati ujian pandemi korona. Peneliti menggunakan metode kajian pustaka (literature review) dengan membaca literatur yang relevan dengan riset ini. Dapat disimpulkan bahwa perlu usaha serius untuk menggali dan meneguhkan nilai ajaran Islam pada aspek individual dan sosial. Dari aspek individual antara lain keimanan pada qada dan qadar, bersikap sabar dan bertawakal. Pada aspek sosial antara lain peduli sesama dan taat kepada Ulama serta pemerintah. Musibah yang mendunia ini pun juga membutuhkan iman yang rasional sebagai panduan dalam bersikap dan beragama dalam keseharian.
\end{abstract}

Kata kunci: iman, sabar, tawakal, rasional

\section{Pendahuluan}

Bagi umat beragama, setiap peristiwa mengandung makna teologis. Demikian halnya jika dikaitkan dengan wabah korona, yang terjadi sudah beberapa bulan dan dialami manusia di bumi yang kecil ini. Kondisi tersebut harus disikapi dengan tepat dan selalu dihiasi dengan harapan. Harapan adalah kekuatan, keyakinan bahwa semua persoalan pasti ada solusinya. ${ }^{373}$ Dengan harapan, bekal melewati ujian akan cukup. Ujian yang diberikan oleh Allah Swt tersebut 
buahnya akan semakin menambah keimanan dan lulus dengan baik, menjadi manusia mulia. ${ }^{374}$

Hanya saja, ironisnya dalam situasi seperti ini, perdebatan teologis muncul ke ruang publik. Misalnya tentang tidak perlu takut dengan korona jika berada di masjid. Bahwa sakit dan kematian sudah ditetapkan, tidak perlu takut. Menolak fatwa untuk sementara tidak perlu shalat berjamaah, tarawih, dan shalat Idul Fitri. Menuding ulama yang berfatwa kurang ilmu dan tidak beriman kepada takdir.

Apabila membaca sikap-sikap yang diungkapkan melalui media sosial tersebut, harus diakui nalar keberagamaan umat Islam masih jauh dari mencerahkan. Ilmu pengetahuan belum sepenuhnya menjadi panduan. Padahal Islam sejalan dengan ilmu pengetahuan. Beriman pada qada dan qadar belum utuh dipahami. Sikap bersabar dan bertawakal tak sepenuhnya dijalankan.

Lantas nilai keimanan yang seperti apa yang harus digali dan dikukuhkan? Model iman seperti apa yang harus dikuatkan? Tentu saja semua sudah memiliki perspektif yang hampir sama bahwa dalam situasi seperti ini, manusia harus memiliki kesabaran, ketawakalan, keimanan pada qada dan qadar. Secara individual, hal ini sangat diperlukan, agar sanggup melewati gelombang ujian yang dahsyat.

Saat ini manusia sedang mendapatkan sesuatu yang tidak diharapkan. Diuji dengan kelaparan, ketakutan, kesusahan dan kegagalan. Dalam ajaran Islam, apapun yang terjadi adalah bagian dari kehidupan yang harus disikapi dengan kesabaran. Kegagalan, kesusahan dan peristiwa lain yang menyakitkan harus dijadikan pelajaran berharga untuk lebih meningkatkan kualitas diri sehingga menemukan strategi pencapaian yang lebih baik.

Hati dan pikiran adalah kunci dalam menyikapi semua masalah yang mendera setiap jiwa. Harmonisasi pikiran dan hati merupakan sumber kebahagiaan. Pikiran yang jernih bagaikan mata air yang mengalir deras dan membawa manusia kepada derajat yanglebih tinggi.Jiwa yang optimis merupakan dua unsuryang mampu menciptakan pemikiran yang harmonis. Inilah yang di dalam istilah agama Islam sebagai potensi ruhani. ${ }^{375}$

374. Iu Rusliana, Ramadhan di Tengah Wabah Corona, Saatnya Naik Kelas Jadi Manusia Mulia, Jakarta: https:// www.muslim .okezone.com yang diakses pada hari Rabu, 22 April 2020 jam 9.10 WIB

375. Ibid.,64 
Selain bersabar, bagi seorang Muslim, qada dan qadar adalah bagian dari keimanan. Memahami makna qada dan qadar secara utuh dalam kehidupan multak diperlukan. Pemahaman terhadap qada dan qadar akan menentukan tujuan dan sikap seorang Muslim dalam menghadapi berbagai peristiwa yang terjadi dalam hidup. ${ }^{376}$

Islam tak hanya menekankan ibadah pada aspek individual. Secara sosial, sikap peduli sesama dan taat pada ulama juga pemerintah menjadi bagian penting dalam upaya mempercepat meredanya wabah ini. Fatwa yang dihasilkan adalah untuk kemaslahatan umat. Kebijakan yang dilakukan, terlepas dari berbagai kekurangan dan problematika lapangannya, tentu ditujukan untuk kepentingan rakyat.

Selain hal tersebut, mendesak juga untuk mengembangkan sikap beragama yang rasional, dipandu oleh ilmu pengetahuan. sikap anti ilmu pengetahuan adalah keterbelakangan. Korona tak akan hilang hanya oleh doa. Korona harus dicarikan vaksinnya dan langkah efektif membatasi penyebarannya. Artikel sederhana ini, akan menjelaskan keimanan individual, sosial dan rasional dalam menghadapi pandemic korona.

Ada sejumlah nilai dalam ajaran Islam yang dapat dikuatkan, mulai dari yang berdimensi individual, hingga bersifat sosial. Selanjutnya, perlu juga diteguhkan iman yang rasional, yang dipandu oleh ilmu pengetahuan. Di bawah ini, penulis deskripsikan penjelasannya lebih lanjut.

\section{Aspek Individual}

\section{a. Iman Pada Qada dan Qadar}

Kata takdir berasal dari akar kata qadara yang memiliki arti mengukur, memberi kadar atau ukuran, sehingga jika manusia berkata Allah telah menakdirkan demikian. Maka itu berarti, Allah telah memberi kadar/ukuran/batas tertentu dalam diri, sifat, atau kemampuan maksimal makhluk-Nya. ${ }^{377}$ Dalam Alquran, qadar juga menyiratkan kekuatan dan pengetahuan Tuhan. Seyyed Hossein Nasr dalam hal ini, menekankan bahwa kata qadar telah diperlakukan secara berbeda oleh berbagai pemikir Islam seperti para ahli hukum, para sufi, para filsuf dan para teolog sesuai dengan fokus mereka masing-masing. ${ }^{378}$

376. Muh. Dahlan Thalib, Takdir dan Sunatullah: Suatu Kajian Tafsir Maudhu'i, Al-Islah:Jurnal Pendidikan Islam (2015), 28-38

377. Ibid

378. Wan Fariza Alyati Wan Zakaria, Qadar in Classical and Modern Islamic Discourses: Commending a Futuristic Perspective, International Journal of Islamic Thought, Vol. 7: ( 2015), 41 
Dapat disimpulkan bahwa qadar adalah salah satu sifat Allah Swt.Bermakna kuasa atas menetapkan sesuatu,apakah ketetapan itu mulia,sempit dan lapang. Dapat pula disimpulkan bahwa qadar Tuhan menetapkan dalam bentuk berpasang-pasangan yakni ada yang lapang ada pula yang sempit,ada yang mulia dan ada yang terhina,dan ada yang baik ada pula yang buruk.Oleh sebab itu,M. Quraish Shihab mengatakan bahwa"Manusia tidak dapat luput dari takdir,yang baik maupun buruk. ${ }^{379}$

Selanjutnya, kata qada, yang berarti hukum,kepastian, penjelasan dan penciptaan. Maknaaslinya ialah memutuskan, memisahkan, menentukan, mengukuhkan, menjalankan dan menyelesaikan. Dalam memahami qada dan qadar dari sudut istilah, menurut al-Bayjuri, pandangan dipelopori oleh ulama Asy'ariyah yang mengatakan bahwa qada mendahului qadar. Hal ini bisa dilihat dari pandangan Ibn Hajar yang mengatakan bahwa qada ialah hukum ketentuan keseluruhan yang bersifat ijmali pada azali. Sedangkan qadar ialah perkara juz'i dan perincian daripada hukum ketentuan tersebut. ${ }^{380}$

Qada dan qadar adalah dua hal yang tidak dapat dipisahkan di antara keduanya. Menekankan dua elemen penting yang saling terkait dan harus ada dalam membangun pemahaman konsep takdir, yang pertama dari semua pengetahuan Allah yang dapat sepenuhnya ditulis dalam lauh mahfuz. Kedua adalah penciptaan makhluk berdasarkan ketetapan dan berdasarkan ilmu-Nya. Hal ini juga didukung oleh al-Jurjani yang mendefinisikan takdir sebagai suatu ketentuan terhadap semua makhluk yang kemudian Allah menetapkan baik, buruk maupun yang lainnya. ${ }^{381}$

Dapat disimpulkan bahwa qada ialah ilmu yang terdahulu yang Allah Swt menghukumi sesuatu pada azali. Sedangkan qadar ialah pelaksanaan perkara yang telah ditetapkan atas makhluk. Kalau disederhanakan, pemahaman terhadap qada dan qadar itu bisa dipahami bahwa apapun yang terjadi di bumi ini, pasti ada sebabnya, termasuk kematian, rezeki dan jodoh pun tunduk pada hukum ini. Dalam hal ini dapat dikatakan bahwa hukum sebab akibat inilah yang kemudian disebut dengan sunnatullah. Dengan kata lain, qada adalah ketetapan yang sudah Allah Swt tentukan sebelumnya. Dalam prinsip Islam, segala yang ada di muka bumi ini mengikuti sunnatullah, aturan Allah Swt. Sedangkan Qadar adalah ukuran dari aturan- aturan

\footnotetext{
379. Thalib, Takdir dan Sunatullah: Suatu Kajian Tafsir Maudhu'i , 31

380. Muhammad Hazim \& Syed Mohammad Hilmi, "Metodologi al-Asha irah dan al-Salafiyyah dalam Membentangkan Akidah," Afkar Vol. 19 Issue 2 (2017): 1-32 381. Ibid
} 
tersebut. Besar kecil (ukuran) usaha atau ikhtiar dalam mengikuti aturan tersebut akan menentukan hasil. Oleh karena itu, hasil dari usaha inilah yang disebut dengan takdir. ${ }^{382}$

\section{b. Sabar}

Sabar adalah konsep yang penting baik secara teologis maupun aspek sosial kemasyarakatan. Ada banyak ayat yang menyampaikan pentingnya kesabaran. Misalnya firman Allah Swt sebagai berikut:

"Dan bersabarlah kamu bersama-sama dengan orang-orang yang menyeru Tuhannya di pagi dan senja hari dengan mengharap keridhaan-Nya; dan janganlah kedua matamu berpaling dari mereka (karena) mengharapkan perhiasan kehidupan dunia ini; dan janganlah kamu mengikuti orang yang hatinya telah Kami lalaikan dari mengingati Kami, serta menuruti hawa nafsunya dan adalah keadaannya itu melewati batas. ${ }^{383}$

Sabar merupakan salah satu modal internal yang dimiliki manusia. Secara etimologi, diartikan sebagai menahan pada tempat yang sempit. Selanjutnya, jika kata sabar dikaitkan dengan manusia, maka dapat berarti menahan jiwa dari hal-hal yang dapat dibenarkan oleh logika dan wahyu. Sedangkan, menurut Quraish Syihab, sabar artinya menahan diri dari sesuatu yang tidak berkenan di hati. ${ }^{384}$

Melihat makna sabar dari segi istiliah, dapat dipahami bahwa sabar berkaitan erat dengan perasaan dan emosi manusia. Karena sabar bermakna kemampuan mengendalikan emosi, maka nama sabar berbeda-beda tergantung objeknya:

1. Ketabahan menghadapi musibah, disebut sabar, kebalikannya adalah gelisah dan keluh kesah;

2. Kesabaran menghadapi godaan hidup nikmat disebut mampu menahan diri (dhobith an nafs), kebalikannya adalah tidaktahanan;

3. Kesabaran dalam peperangan disebut pemberani, kebalikannya disebut pengecut;

4. Kesabaran dalam menahan marah disebut santun (hilm), kebalikannya disebut pemarah;

382. Muh. Dahlan Thalib, Takdir dan Sunatullah: Suatu Kajian Tafsir Maudhu'I, Al-Islah:Jurnal Pendidikan Islam (2015), 30

383. Al-Qur'an, 18: 28

384. M. Yusuf dan Dona Kahfi, Sabar dalam Perspektif Islam dan Barat, Al-Murabbi, Vol. 4. No. 2 (2018), 237 
5. Kesabaran dalam menghadapi bencana yang mencekam disebut lapang dada, kebalikannya disebut sempit dadanya;

6. Kesabaran dalam mendengar gosip disebut mampu menyembunyikan rahasia;

7. Kesabaran terhadap kemewahan disebut zuhud, kebalikannya disebut serakah;

8. Kesabaran dalam menerima yang sedikit disebut kaya hati (qana'ah) kebalikannya disebut tamak atau rakus ${ }^{385}$

Dari penjelasan tentang makna sabar berdasarkan objeknya, dapat dipahami bahwa sabar adalah sifat yang bisa dilatih. Dari kisah Nabi Yusuf as. dan pemuda Kahfi, Al-Qur'an telah menggambarkan beberapa cara untuk membiasakan sikap sabar, antara lain adalah dengan:

1. Menanamkan keyakinan adanya balasan yang baik bagi orang-orang yang sabar. Keyakinan semacam ini merupakan sesuatu hal yang sangat penting membantu seseorang agar dapat bersifat sabar;

2. Mengingatkan bahwa orang yang paling dekat dengan Allah pun, seperti nabi dan rasul senantiasa memperoleh cobaan, bahkan bentuk cobaannya lebih berat lagi dibandingkan dengan kebanyakan manusia;

3. Menanamkan keyakinan adanya kemudahan setelah kesusahan, dan janji-janji Allah tersebut sebagai suatu kepastian;

4. Menanamkan kesadaran, bahwa manusia itu milik Allah;

5. Mengingatkan adanya sunnatullah atau hukum alam yang berlaku di dunia;

6. Menanamkan keyakinan tentang qada dan qadar Allah yang tidak mungkin dapat dihindari. ${ }^{386}$

\section{c. Tawakal}

Berserah diri kepada Allah, dalam Islam, disebut dengan tawakal. Tawakal diharuskan ketika manusia sudah tidak mampu lagi mengendalikan keadaan. Namun, terkadang banyak Muslim yang keliru dalam memaknai tawakal. Mereka menyerahkan segalanya kepada Allah Swt tanpa ada usaha sedikitpun. Padahal, tawakal diwajibkan ketika keadaan di luar kemampuan manusia untuk merubahnya dan tidak diharuskan tawakal ketika masih ada kemungkinan dan

385. Ibid., 236

386. Ibid.,238-239 
kemampuan untuk mengubahnya. Orang-orang yang pasrah dan tidak berusaha, hanya semata-mata bertawakal kepada Allah, adalah orang-orang yang dusta. ${ }^{387}$

Kata tawakal diambil dari bahasa Arab adalah turunan dari kata wakil. Wakil adalah dzat atau orang yang dijadikan pengganti untuk mengurusi atau menyelesaikan urusan yang mewakilkan. Sehingga tawakal bermakna menjadikan seseorang sebagai wakilnya, atau menyerahkan urusan kepada wakilnya. Tawakal kepada Allah berarti menjadikan Allah sebagai wakil untuk mengurusi segala urusan, dan mengandalkan Allah untuk menyelesaikan segala urusan. ${ }^{388}$

Makna tawakal menurut Quraish Shihab, sebagaimana dikutip Abdul Ghoni, tidak berarti penyerahan mutlak kepada Allah, tetapi penyerahan tersebut harus didahului dengan usaha manusiawi. ${ }^{389}$ Dengan demikian, tawakal bukan berarti tak ada upaya, tapi harus dimulai dengan ikhtiar semaksimal mungkin, hasilnya diserahkan sepenuhnya kepada Allah Swt. ${ }^{390}$

Selanjutnya, menurut Ibnu Al-Qayyim: "Tawakal adalah tidak tampak pada dirimu ketergantungan kepada sebab, walaupun engkau sangat butuh kepadanya, dan tidak hilang ketenangan-Mu kepada Al-Haq (Allah) walaupun engkau telah mendapatkannya (kebutuhanmu)."391

Selanjutnya, melaksanakan tawakal harus memenuhi beberapa komponen. Mengenai hal ini, Ibnu al-Qayyim menyebutkan beberapa unsur yang harus dipenuhi. Jika tidak terpenuhi, maka tidak akan pernah mencapai hakikat tawakal. Pertama, mengenal Nama Allah dan sifat-Nya. Kedua, menetapkan (meyakini sebab dan musabab). Ketiga, kedalaman tauhid dalam tauhid tawakal dengan melepaskan ketergantungan dengan sebab. Keempat, penyandaran hati kepada Allah dan ketenangan kepada-Nya. Kelima, pasrah hati kepada Allah, seperti pasrahnya mayit kepada yang memandikannya. Keenam, penyerahan kepada Allah terhadap apa yang Allah takdirkan. Ketujuh, ridha dengan segala hasil. Sebagaimana yang tergambar dalam doa istikharah untuk dipilihkan apa yang baik untuk Allah. ${ }^{392}$

387. Abdul Ghoni, Konsep Tawakal Dan Relevansinya Dengan Tujuan Pendidikan Islam: Studi Komparasi Mengenai Konsep Tawakal Menurut M. Quraish Shihab Dan Yunan Nasution, An-Nuha, Vol. 3. No. 1 (2016), 111

388. Muh. Mu'inudinillah Basri, Indahnya Tawakal, (Solo: Indiva Media Kreasi, 2008), h. 15-16

389. Abdul Ghoni, Konsep Tawakal Dan Relevansinya Dengan Tujuan Pendidikan Islam: Studi Komparasi Mengenai Konsep Tawakal Menurut M. Quraish Shihab Dan Yunan Nasution,112

390. M QuraishShihab, Corona Ujian Tuhan; Sikap Muslim Menghadapinya, Tangerang Selatan: Lentera Hati, 2020, 80

391. Muh. Mu'inudinillah Basri, Indahnya Tawakal, 19

392. Muh. Mu'inudinillah Basri, Indahnya Tawakal, 20-21 


\section{Aspek Sosial}

\section{a. Peduli Sesama}

Pandemi korona telah memiskinkan banyak orang dengan tiba-tiba. Terjangkitnya virus karena interaksi, padahal mereka adalah petugas kesehatan, dan berbagai sektor yang lumpuh. Pemutusan hubungan kerja, bisnis yang tersendat, kemiskinan dan kejahatan merajalela. Situasi ini mendorong manusia beriman untuk peduli sesama. Esensi ajaran Islam adalah peduli sesama. Dimana kepedulian adalah kekuatan, bangunan yang saling mengokohkan. Tidak beriman seseorang jika tidak mencintai saudaranya sebagaimana mencitai diri sendiri.

Pada dasarnya, manusia akan saling membutuhkan. Oleh sebab itu, tugas manusia di dunia adalah saling melengkapi antara satu dengan yang lainnya. Hal ini sesuai dengan firman Allah Swt: Apakah mereka yang membagi-bagi rahmat Tuhanmu? Kami telah menentukan antara mereka penghidupan mereka dalam kehidupan dunia, dan Kami telah meninggikan sebahagian mereka atas sebagian yang lain beberapa derajat, agar sebagian mereka dapat mempergunakan sebagian yang lain. dan rahmat Tuhanmu lebih baik dari apa yang mereka kumpulkan. ${ }^{393}$

Perbedaan yang terjadi bukan untuk dipertentangkan apalagi sampai melahirkan pertentangan antar kelas, namun untuk dipertemukan dalam bingkai ta'awun. Terutama sekali Saat ini, bangsa Indonesia sedang menghadapi musibah pandemi yang luar biasa, namanya virus korona. Menghadapi fenomena seperti ini, sudah seharusnya Muslim tergugah hatinya untuk membantu sesama dan meningkatkan kepedulian. Tolong menolong dan bersinergi antara sesama orang yang beriman termasuk antara orang miskin dan orang kaya, akan melahirkan kekuatan. ${ }^{394}$

Sikap peduli kepada sesama dan keinginan membantu orang lain adalah bagian dari kecerdasan emosi. Kecerdasan emosi merupakan kemampuan untuk mengelola perasaan, kemampuan untuk mempersepsi situasi, bertindak sesuai dengan persepsi dan menentukan potensi seseorang untuk mempelajari keterampilan praktis yang didasarkan pada kesadaran diri, motivasi, empati dan kemampuan dalam menjalin hubungan dengan orang lain. ${ }^{395}$

393. Al-Qur'an, surat az-Zukhruf 43:32

394. Lajnah Pentashihan Mushaf, "Al-Qur'an, Tafsir al-Qur'an Tematik", Jakarta: Kamil Pustaka, 2014), 346

395. Aditia, Hana Rizkia, Hamiyati Hamiyati, and Rusilanti Rusilanti. "Hubungan Pola Asuh Orang Tua dengan Kepedulian Sosial Remaja." Jurnal Kesejahteraan Keluarga dan Pendidikan 3.2 (2016): 89-93. 
Rasulullah SAW menganjurkan Muslim untuk saling membantu, menguatkan dan bersinergi. Rasulullah bahkan mengilustrasikan hubungan antara Muslim itu seperti satu bangunan yang saling mengokohkan atau ibarat satu tubuh yang jika satu anggotanya sakit, maka anggota tubuh yang lainnya akan merasakan sakit. "Orang mukmin terhadap orang mukmin yang lainnya ibarat sebuah bangunan yang saling menguatkan antara satu dengan yang lainnya." 396

Selanjutnya, Islam sangat memberikan perhatian besar terhadap kaum dhuafa. Hal ini bisa dilihat dari cara pengeluaran harta (al-mal). Berikut ini dikemukan beberapa contoh:

1. Zakat, diutamakan untuk kesejahteraan fakir miskin yang merupakan mustahiq utamanya;

2. Infak dan sedekah salah satu fungsinya untuk menyejahterakan fakir-miskin, disamping untuk kerabat, ibnu sabil, maupun anak yatim;

3. Wakaf yang memberikan kemanfaatan bagi kepentingan umum;

4. Fidyah bagi yang tidak mampu berpuasa diberikan untuk orang-orang miskin;

5. Kifarat sumpah salah satu alternatif dari kifarat sumpah adalah memberikan makanan atau pakaian kepada fakir miskin.

Peduli sesama diibaratkan sebagai al-aqabah (menaiki tangga yang berat), memperhatikan orang miskin akan mendapatkan pahala yang besar dari Allah SWT. ${ }^{397}$ Ajaran Islam menumbuhkan dan membangkitkan semangat kaum dhuafa yang sewaktu-waktu bisa jadi pemimpin dan pewaris kepemimpinan di muka bumi. Sebaliknya, tidak memperhatikan mereka melalui programprogram konkret, dianggap sama dengan mendustakan agama. ${ }^{398}$

Sudah jelas bahwa agama memerintahkan kepedulian dan pemberdayaan orang miskin. Muslim harus bekerjasama dan saling menguatkan dalam menghadapi musibah ini. Jangan membiarkan orang disekeliling rumah mati kelaparan. Ketenangan akan didapatkan oleh orang yang memiliki kepedulian kepada fakir miskin. Al-Qur'an juga mengingatkan bahwa orang yang acuh terhadap fakir miskin disekelilingnya akan mendapakan kegelisahan dalam hidupnya. ${ }^{399}$

396. HR. Bukhari dan Muslim

397. Tafsir al-Qur'an Tematik,347-349

398. Al-Qur'an, surat al-Ma'un, 107:1-3

399. Lajnah Pentashihan Mushaf, “ Al-Qur'an, Tafsir al-Qur'an Tematik”, Jakarta: Kamil Pustaka, 2014), 349 


\section{b. Taat Kepada Ulama dan Pemerintah}

Saat ini manusia khususnya umat Islam dihadapkan pada ketakutan dan kecemasan yang bagi beberapa orang mungkin tidak berkesudahan. Menghadapi fenomena seperti ini, tentu umat Islam harus menyerahkan segala betuk keputusan kepada pemerintah. Allah Swt berfirman:

"Dan apabila datang kepada mereka suatu berita tentang keamanan ataupun ketakutan, mereka lalu menyiarkannya. Dan kalau mereka menyerahkannya kepada Rasul dan Ulil Amri di antara mereka, tentulah orang-orang yang ingin mengetahui kebenarannya (akan dapat) mengetahuinya dari mereka (Rasul dan Ulil Amri). Kalau tidaklah karena karunia dan rahmat Allah kepada kamu, tentulah kamu mengikut syaitan, kecuali sebahagian kecil saja (di antaramu). 400

Ketaatan dan kepatuhan kepada Ulil Amri menjadi sebuah kewajiban sebagaimana disebutkan dalam Al-Qur'an dan Hadits Nabi. Di antara firman Allah ta'ala adalah:

"Hai orang-orang yang beriman, taatilah Allah dan taatilah Rasul (Nya), dan ulil amri di antara kamu. Kemudian jika kamu berlainan pendapat tentang sesuatu, maka kembalikanlah ia kepada Allah (Al Quran) dan Rasul (sunnahnya), jika kamu benar-benar beriman kepada Allah dan hari kemudian. Yang demikian itu lebih utama (bagimu) dan lebih baik akibatnya." 401

Selain ayat yang telah disebutkan, ada juga hadis Rasulullah Saw yang menganjurkan umat Islam untuk taat kepada Ulil Amri/pemimpin. Rasulullah Saw bersabda:" Barang siapa menaati aku sungguh ia telah menaati Allah, dan barang siapa yang durhaka padaku sungguh ia telah mendurhakai Allah, barang siapa yang taat kepada pemimpin sungguh ia telah taat kepadaku, dan barang siapa yang durhaka kepada pemimpin sungguh ia telah durhaka kepadaku." 402

Dalam Al-Qur'an dan hadist sudah jelas bahwa Ulil Amri menempati posisi ketiga yang mesti diikuti setelah Allah Swt dan Rasul Saw. Maksud Ulil Amri menurut Ibnu Taimiyah adalah orang yang memerintah, terdiri dari al-Umara (para kepala negara) dan al-Ulama (para sarjana). Adapun al-Umara adalah pemegang kekuasaan eksekutif, sedangkan al-Ulama adalah pemegang kekuasaan ilmu pengetahuan, fatwa dan legislatif. ${ }^{403}$

Berdasarkan paparan di atas, sudah jelas bahwa taat kepada Ulil Amri/ Umara adalah suatu kewajiban yang harus ditaati oleh setiap Muslim. Bahkan, di

400 Al-Qur'an surat An-Nisa: 83

401 Al-Qur'an surat An-Nisa: 59

402 HR. Muslim

403 Ibid.,96-97 
antara dasar aqidah ideologi ahlus sunnah wal jamaah adalah mewajibkan untuk menaati para pemimpin kaum muslimin selagi mereka tidak memerintahkan kepada kemaksiatan. Jika mereka memerintahkan kepada kemasiatan, Muslim tidak boleh mamatuhi mereka dan kepatuhan kepada mereka secara ma'ruf masih tetap (ada) pada selain kemaksitan karena mengamalkan firman Allah ta'ala. Ahlus sunnah wal jamaaah berpendapat bahwa menaati pemimpin secara ma'ruf merupakan salah satu dasar utama aqidah. Ketaataan adalah kewajiban syar'i atas setiap muslim karena merupakan perkara yang mendasar untuk mewujudkan ketertiban dalam negeri Islam. ${ }^{404}$

Ketaatan seorang Muslim kepada pemimpin memang ada batasannya. Seorang Muslim hanya boleh patuh kepada pemerintah atau pemimpin selama tidak memerintahkan kepada keburukan. Oleh sebab itu, dalam surat An-Nisa ayat 59, kata țā'at tidak diulangi ketika menyebut Ulil Amri, menurut Sayyid Quṭb menunjukkan bahwa ketaatan Muslim kepada Ulil Amri hanya mengikuti taat kepada Allah dan Rasul.405

Kalaupun pemimpin melakukan kesalahan dan melanggar aturan Allah dan Rasul, seorang Muslim harus tetap menunjukan etika yang baik. keutuhan sebuah bangsa harus diutamakan dibandingkan kepentingan pribadi atau kelompok. Imam an-Nawawi mengatakan bahwa menasihati para pemimpin kaum muslimin adalah dengan menolong mereka atas kebenaran, menaati mereka didalamnya, dan memerintahkan mereka kepadanya, mengingatkan mereka dengan lemah lembut, dan memberitahukan kepada mereka tentang apa yang telah mereka lalaikan. ${ }^{406}$

\section{c. Iman Yang Rasional}

Belajar dari pandemi korona yang terjadi, umat Islam di Indonesia membutuhkan iman yang rasional. Iman yang salah satu dasarnya ilmu pengetahuan. Bukan iman yang anti ilmu pengetahuan. Tuna ilmu pengetahuan, menjadikan umat Islam mengalami keterbelakangan. Tuhan menjanjikan derajat yang lebih tinggi bagi mereka yang beriman, beramal saleh dan berilmu pengetahuan sebagaimana dinyatakan dalam surah Al-Mujadalah ayat 11.407

404 Prima Ayu dan Umi Hanik, Sikap Ahlus Sunnah Terhadap Pemerintah Republik Indonesia Yang Berideologi Pancasila, NIZHAM, Vol. 06, No. 01 (2018), 76

405. Bukhori Abdul Somad, Etika Pemerintahan: Kontribusi Tafsir Fi Zilal Al-Qur'an Karya Sayyid Qutb, TEOLOGIA, VOLUME 22, NOMOR 2, (2011), 14

406. Prima Ayu dan Umi Hanik, Sikap Ahlus Sunnah Terhadap Pemerintah Republik Indonesia Yang Berideologi Pancasila,76

407. Iu Rusliana, Ramadhan dan Kebangkitan Umat, Jakarta, Koran Republika, Rabu 29 April 2020, 05:03 WIB di https: www.republika.co.id, diakses pada hari Rabu, 29 April 2020 jam 10.12 WIB. 
Untuk memahami iman yang rasional, ada baiknya merujuk kepada pemikiran Muhammad Abduh. Menurut Abduh, kemajuan agama Islam itu tertutup oleh umat Islam sendiri, di mana umat Islam beku dalam memahami ajaran Islam. Dihapalkan lafadznya, tapi tidak berusaha mengamalkan isi kandungannya. Kedua, akal mempunyai kedudukan yang sangat tinggi dalam agama Islam. Sehingga ada ungkapan:"Agama adalah sejalan dengan akal dan tidak ada agama bagi orang yang tidak menggunakan akal". Akal diyakini akan mampu menyingkapkan misteri alam semesta yang diciptakan Allah untuk kesejahteraan manusia itu sendiri. Hanya dengan ketinggian akal dan ilmu manusia bisa mendudukan dirinya sebagai makhluk yang tunduk dan berbakti kepada sang pencipta. Ketiga, ajaran Islam sesuai dengan perkembangan ilmu pengetahuan modern begitu pula ilmu pengetahuan modern pasti sesuai dengan ajaran Islam. Abduh berpendapat bahwa antara ilmu dan iman tidaklah mungkin saling kontradiktif. ${ }^{408}$

Dari apa yang disampaikan Abduh, tegas bagaimana agar ilmu pengetahuan menjadi bagian utama dalam kemajuan umat Islam. Jangan pernah meninggalkan ilmu pengetahuan dan menumbuhsuburkan iman yang irrasional. Harun Nasution sebagaimana dikutip oleh Firdausy, mengatakan bahwa iman sangat erat kaitannya dengan akal dan wahyu. Iman yang didasarkan pada wahyu disebut tasdiq, yaitu menerima sebagai benar apa yang didengar. Sedangkan iman yang didasarkan pada akal disebut ma'rifah, yang berarti mengerti benar dengan apa yang diyakini. Jadi tasdiq berdasarkan pada pemberitaan, sedangkan ma'rifah berdasarkan pada pengetahuan mendalam.

Di sisi yang lain, Muhammad Abduh juga menyatakan bahwa iman adalah pengetahuan, kepercayaan atau keyakinan. Dalam Tafsir al-Manar, ia menjelaskan bahwa iman adalah pengetahuan sebenarnya yang diperoleh akal melalui berbagai argumen yang kuat untuk membawa seseorang kepada ketundukan dan kepasrahan kepada Allah. Hal ini berarti bahwa iman tidaklah sempurna kalau tidak didasarkan atas akal. Iman harus berdasar pada keyakinan, bukan pada pendapat, dan akal yang menjadi sumber keyakinan pada Tuhan, ilmu serta kemahakuasaan-Nya serta para Rasul. ${ }^{409}$

Harun Nasution dengan teologi pembaharuannya, mendorong untuk mengkaji ulang ajaran Islam dengan menggunakan nalar rasional yang Islamis agar umat Islam memiliki kemampuan untuk merespon perubahan globalisasi

408. Ibid., 246-259

409. Firdausy, Muhammad Anwar. "Kritik Atas Iman." El Harakah 8.1 (2006): 115. 
dan mampu bangkit dari keterbelakangan. Harun Nasution sebagaimana dikutip oleh Suryanta dan Nuryanti menyatakan bahwa akal mampu menjawab masalah mengenai Tuhan, kewajiban mengenai Tuhan, mengetahui yang baik dan jahat, dan kewajiban mengerjakan yang baik dan menjauhi yang jahat. Sedangkan fungsi wahyu dalam pandangan Harun Nasution adalah sebagai pelengkap saja yang dapat diketahui manusia melalui penggunaan akalnya. ${ }^{410}$

Iman yang rasional adalah meletakkan akal sebagai basis dalam Islam. Akal dan ilmu pengetahuan tidak bertentangan dengan Islam. Sebagaimana diyakini Muhammad Abduh, kemunduran umat Islam bukanlah disebabkan penjajahan yang dilakukan oleh dunia Barat, akan tetapi kemunduran umat Islam dikarenakan ketertinggalan berpikir dan kebodohan. Umat Islam haruslah terbebas dari keterbelakangan dan kebodohan. ${ }^{411}$

Abduh menekankan pentingnya akal dalam memahami ajaran agama. Muhammad Abduh berpendapat bahwa metode al-Qur'an dalam memaparkan ajaran-ajaran agama berbeda dengan metode yang ditempuh oleh kitab-kitab suci sebelumnya. Al-Qur'an tidak menuntut untuk menerima begitu saja apa yang disampaikan, tetapi memaparkan masalah dan membuktikannya dengan argumentasi, bahkan menyampaikan pandangan penentangnya sambil membuktikan kekeliruan mereka. ${ }^{412}$

Umat Islam harus menjadikan akal sebagai kekuatan. Islam, secara telologis merupakan sistem nilai dan ajaran yang bersifat ilahiyyah-transenden. Dalam realitas sosialnya, Islam tidak lagi sekedar doktrin yang bersifat menjaman tetapi juga mengejawantah dalam lemabaga atau institusi sosial yang selalu dipengaruhi oleh situasi ruang dan waktu. ${ }^{413}$

Abduh, dalam kitabnya "al A'maal al Kaamilah", telah meletakkan dasardasar sebagai jalan menuju reformasi keagamaan, salah satu dasarnya adala pentingnya analisis rasional dalam mencapai iman yang paripurna. Iman tidak lahir dari seorang hakim, baik hakim agama maupun politik. Iman datang dari sebuah penghayatan dan pemahaman yang benar terhadap wahyu, tekstual maupun non-tekstual. Selanjutnya, wahyu tidak dapat membawa hal-hal yang bertentangan dengan akal. Kalau dzahir ayat atau hadis bertentangan dengan

\footnotetext{
410. Ibid., 1-19

411. Fadholi, M., Muhammad Aziz, and Hery Purwanto. "Dimensi Rasional Dalam Pemikiran Muhammad Abduh 1849-1905 (Studi Bidang Pendidikan, Politik Dan Sosial-Keagamaan)." Al Hikmah: Jurnal Studi Keislaman 9.2 (2019): 246-259.

412 Ibid., 249

413. Ibid, 249
} 
akal, maka harus dicari interpretasi yang membuat ayat dapat dipahami secara rasional. Kepercayaan pada kekuatan akal adalah dasar peradaban bangsa. Oleh sebab itu, Abduh sangat mendukung adanya ijtihad dan menghilangkan kejumudan dari kehidupan umat Islam.

Jumud yang dipahami oleh Abduh mengandung arti kestatisan, tiadanya perubahan. Ummat Islam harus dihindarkan dari kebekuan tersebut, dan mereka harus mau menerima perubahan. Muhammad Abduh melihat perlunya tentang upaya pembongkaran kejumudan dan mulai melahirkan ide tentang perlunya melaksanakan ijtihad. Bukan tanpa alasan, Muhammad Abduh meyakini bahwa keadaan masyarakat dari waktu ke waktu akan tersu berkembang. Menghadapi perkembangan jaman yang begitu cepat, maka dibutuhkan ijtihad. Muhammad Abduh sangat menentang taqlid yang dipandangnya sebagai faktor yang melemahkan jiwa kaum muslimin. ${ }^{414}$

\section{Penutup}

Dari paparan di atas, dapat disimpulkan bahwa pandemi korona dapat menjadi momentum meneguhkan kembali nilai-nilai keislaman seperti sikap sabar, tawakal, konsep keimanan kepada takdir, peduli sesama dan taat kepada pimpinan. Situasi ini juga dapat mendorong pada upaya menguatkan pentingnya iman yang rasional, anti takliq buta dan yang berdasarkan ilmu pengetahuan. Islam adalah agama yang selaras dengan ilmu pengetahuan.

414. Ibid, 249 


\section{Daftar Pustaka}

Aditia, Hana Rizkia, Hamiyati, dan Rusilanti. "Hubungan Pola Asuh Orang Tua dengan Kepedulian Sosial Remaja." Dalam Jurnal "Kesejahteraan Keluarga dan Pendidikan" Volume 3 Nomor 2016) 2)

Basri, Muhammad Mu'inudinillah, Indahnya Tawakal, Solo: Indiva Media Kreasi, 2008

Bukhori, Abdul Somad, "Etika Pemerintahan: Kontribusi Tafsir Fi Zilal AlQur'an Karya Sayyid Qutb,” dalam Jurnal “Teologia” Volume 22, Nomor 2011) ,2)

Dahlan Thalib, Muh Dahlan, "Takdir dan Sunatullah: Suatu Kajian Tafsir Maudhu'i, dalam Jurnal “Al-Islah:Jurnal Pendidikan Islam” Volume 6 Nomor 2015) 2)

Fadholi, M., Muhammad Aziz, and Hery Purwanto. "Dimensi Rasional Dalam Pemikiran Muhammad Abduh 1905-1849 (Studi Bidang Pendidikan, Politik Dan Sosial-Keagamaan)," dalam Jurnal Al-Hikmah; Jurnal Studi Keislaman, Volume 9 Nomor 2019) 2)

Firdausy, Muhammad Anwar. "Kritik Atas Iman," dalam "Jurnal El Harakah Volume 8 Nomor 125-115:

Ghoni, Abdul. "Konsep Tawakal Dan Relevansinya Dengan Tujuan Pendidikan Islam: Studi Komparasi Mengenai Konsep Tawakal Menurut M. Quraish Shihab Dan Yunan Nasution,"Jurnal An-Nuha", Volume 3 Nomor 1 2016))

Hazim, Muhammad \& Syed Mohammad Hilmi, "Metodologi al-Asha irah dan al-Salafiyyah dalam Membentangkan Akidah,” dalam Jurnal “Afkar"Volume 19 Issue 2017) 2)

Lajnah Pentashihan Mushaf, “Al-Qur'an, Tafsir al-Qur'an Tematik”, Jakarta: Kamil Pustaka, 2014

Prima, Ayu dan Umi Hanik,. "Sikap Ahlus Sunnah Terhadap Pemerintah Republik Indonesia Yang Berideologi Pancasila," dalam Jurnal "Nizham", Volume 06, Nomor 2018) 01)

Rusliana, Iu, "Cahaya Harapan di Tengah Pandemi”, Jakarta: Koran Republika, Senin 20 April 2020

....., "Ramadhan di Tengah Wabah Corona, Saatnya Naik Kelas Jadi Manusia Mulia," Jakarta: https://www.muslim .okezone.com, hari Rabu, 22 April 2020

...., "Ramadhan dan Kebangkitan Umat," Jakarta, Koran Republika, Rabu 29 April 2020

Shihab, M Quraish, Corona Ujian Tuhan; Sikap Muslim Menghadapinya, Tangerang Selatan: Lentera Hati, 2020 
Wan Zakaria, Wan Fariza Alyati, "Qadar in Classical and Modern Islamic Discourses: Commending a Futuristic Perspective," dalam Jurnal "International Journal of Islamic Thought," Volume 21 Nomor 2015 ) 2)

Yusuf, M dan Dona Kahfi, "Sabar dalam Perspektif Islam dan Barat," Jurnal "Al-Murabbi," Volume 4 Nomor 2018) 2) 